Primljen / Received: 22.11.2016. Ispravljen / Corrected: 21.3.2017.

Prihvaćen / Accepted: 24.3.2017.

Dostupno online / Available online: 10.7.2017.

\section{Numerical simulation of effect of explosive action on overpasses}

Authors:

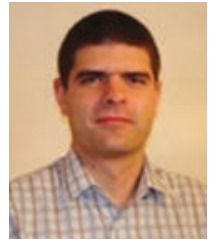

Assist.Prof Hrvoje Draganić, PhD. CE University J. J. Strossmayera in Osijek Faculty of Civil Engineering draganic@gfos.hr

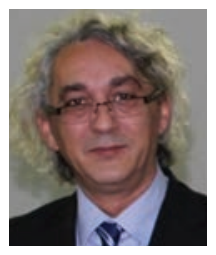

Assoc.Prof. Damir Varevac, PhD. CE University J. J. Strossmayera in Osijek Faculty of Civil Engineering dvarevac@gfos.hr
Hrvoje Draganić, Damir Varevac

Original scientific paper

\section{Numerical simulation of effect of explosive action on overpasses}

Overpasses can not be made absolutely safe to explosive action, regardless of interventions made during their design and/or realisation. This is due to the fact that the very quantity of explosive to be activated under the bridge during an attack can not be defined with an acceptable level of probability. Three quantities of explosives activated under the overpass structure are analysed. The load, behaviour, and damage to overpass superstructure are considered. It is stated in conclusion that all three quantities of explosive afflict considerable damage to usual overpasses, and cause their collapse. The nonlinear numerical analysis of the overpass was conducted using the Ansys Autodyn hydrocode software.

Key words:

explosion wave, pressure area, spatial numerical model, superstructure damage, pressure-impulse diagrams

Izvorni znanstveni rad

Hrvoje Draganić, Damir Varevac

\section{Numerička simulacija djelovanja eksplozije na nadvožnjake}

Nadvožnjak nije moguće učiniti, projektiranjem i/ili izvedbom, apsolutno sigurnim na djelovanje eksplozije jer se ni sama količina eksploziva koja bi se detonirala ispod mosta u nekakvom napadu ne može odrediti s prihvatljivom vjerojatnošću. U radu je analizirano djelovanje tri količine eksploziva detonirane ispod rasponske konstrukcije nadvožnjaka. Promatrano je djelujuće opterećenje, ponašanje i oštećenje rasponskog sklopa nadvožnjaka. Zaključeno je kako sve tri količine eksploziva znatno oštećuju uobičajeni nadvožnjak te uzrokuju rušenje. Nelinearna numerička analiza nadvožnjaka provedena je koristeći hidrokod softver Ansys Autodyn.

Ključne riječi:

val eksplozije, ploha tlakova, prostorni numerički model, oštećenje rasponskog sklopa, tlak-impuls dijagrami

Wissenschaftlicher Originalbeitrag

Hrvoje Draganić, Damir Varevac

\section{Nummerische Simulation der Einwirkung einer Explosion auf Überführungen}

In Übereinstimmung damit wurde die Wirkung von drei Sprengstoffmengen analysiert, die unter der Konstruktion der Überführung detonierten. Beobachtet wurden die einwirkende Belastung, das Verhalten und die Beschädigung am Überbau der Überführung. Es wurde festgestellt, dass alle drei Sprengstoffmengen eine normale Überführung erheblich beschädigen sowie den Einsturz verursachen. Die nicht lineare nummerische Analyse der Überführung wurde durch Anwendung der hidrokod Software Ansys Autodyn durchgeführt.

Schlüsselwörter:

Explosionswelle, Druckflächen, räumliches nummerisches Modell, Beschädigung des Überbaus, Druck-Impuls-Diagramme 


\section{Introduction}

Bridges are considered to be highly sensitive to terrorist attack hazard mostly because all their parts are easily accessible. In case of imminent danger, only big structures can be monitored as it would hardly be possible to provide physical protect for every overpass or underpass.

The vulnerability of bridges to explosions can be estimated by dividing it into three basic groups: explosion on the road passing over the bridge, explosive action affecting the bridge structure itself, and explosion under the bridge. This analysis concerns the third vulnerability group. In this scenario, it is assumed that the explosive will be brought by motor vehicle under an unsupervised bridge, and that the explosive charge will be set off from a certain distance, counting from the bottom edge of the superstructure. Although it is difficult to estimate the quantity of explosive required, a rough estimate can nevertheless be made based on the bearing capacity and trunk volume of vehicles most frequently used on roadways [1, 2] (Table 1). First three quantities specified in the table are the most probable ones. They involve the possibility that the overpass will not collapse; detonation of greater quantities of explosive will certainly result in collapse.

Table 1. Estimated quantity of explosive by vehicle type [1, 2]

\begin{tabular}{|c|c|}
\hline Vehicle type & Quantity of explosive $[\mathrm{kg}]$ \\
\hline Car trunk & 115 \\
\hline Trunk of a bigger car (station wagon) & 230 \\
\hline Closed van & 680 \\
\hline Closed truck & 2270 \\
\hline Trailer truck & 13610 \\
\hline Double-trailer truck & 27220 \\
\hline
\end{tabular}

The effect of explosions on bridge structure can be studied both experimentally and by computer modelling. Studies conducted so far have mostly linked explosion resistance of bridges to seismic resistance, where a higher ductility level ensures higher bridge resistance to explosions. This was established when testing resistance of bridge piers designed according to the US seismic requirements for exposure to different intensities of explosion [35]. In this respect, most tests were conducted on reduced scale models [6-9] as testing on full scale models is both costly and hazardous [10, 11]. Fujikura and Bruneau (2011) [7] conducted ductility testing for ordinary and non-ductile steel-strengthened reinforced-concrete piers in order to determine their resistance to explosions, but none of the pier types tested exhibited ductile behaviour when subjected to load. In fact, failure occurred due to shear at the pier bottom, which was contrary to the assumed bending failure scenario. Based on experimental results, it was concluded that this pier type does not meet requirements regarding resistance to explosions, and that some modifications have to be made. Foglar and Kovar (2013) [13] conducted a full scale in-situ testing (at a military testing range) to determine the effect of explosions on high-strength reinforced-concrete slabs, which were additionally strengthened with microfibres. The slabs were tested using $25 \mathrm{~kg}$ of TNT explosive placed at a predefined distance from the slabs. The results of this experiment show that fibre-reinforced slabs exhibit an improved resistance and higher strength, as evidenced in lower fragmentation and damage, and higher ductility. Despite this and other experiments mentioned in the list of literature, the influence of explosions is still an insufficiently studied area, with most research being made using numerical models and simulations. Computer programs that are used for numerical simulation of explosive action are known as hydrocode programs, and are specialized for simulations in fluid dynamics. These programs are able to simulate detonation processes, propagation of explosive waves, and wave interaction with the structure under study (Ansys Autodyn, LS-Dyna, Abaqus, STADPro) [12-15]. Black [16] analyses the use of the hydrocode software Autodyn for modelling elements subjected to load by explosive action and provides, in this respect, a general description of the program, modelling techniques used, and the way in which explosive action is calculated and simulated. The simulation is made by testing a square concrete plate $(244 \mathrm{~cm} \times 20 \mathrm{~cm})$, being an approximation of a bridge superstructure, which is subjected to explosive action generated by the $45 \mathrm{~kg}$ cube-shaped explosive charge. Anwarul and Yazdani [17] analyse the most frequent bridge type on interstate motorways in the US (double-span two-lane girder bridge, type III, AASHTO) to determine resistance of such structures to explosive action. In this testing, beams, piers and head beams are subjected to load as determined based on predicted explosive action. Numerical model of the bridge, created using the STAAD Pro software, revealed that failure due to explosive action occurs around and under the bridge. The authors conclude that a typical AASHTO bridge can not withstand the assumed explosive action. Based on Autodyn, Deng and Jin [18] present a numerical simulation aimed at analysing the effect of the size of the finiteelement mesh on the pressure distribution and damage to steel truss bridge elements subjected to explosion generated by 800 $\mathrm{kg}$ of TNT placed on the bridge pavement structure. Numerical results reveal damage to some parts of the bridge and enable global understanding of the bridge behaviour when subjected to explosive action. Tank [19] analyses nonlinear response of a cablestayed bridge subjected to explosive action involving $1000 \mathrm{~kg}$ of TNT, using a spatial numerical model operated within the LS-DYNA software. The analysis was conducted in two steps so as to reduce the total calculation time. In the first step, individual parts of the bridge are analysed in detail so as to determine failure mode, while the possibility of bridge collapse is analysed for a pre-determined level of damage in the second step based on loading conditions specified by DoD (US Department of Defence). It was concluded that failure of vertical structural elements (piers and pylons) leads to catastrophic collapse of the bridge. Tang and Hao [20] present a numerical simulation of dynamic response of a cable-stayed bridge to explosive action (LS-DYNA). The authors describe the bridge, provide an estimate of load by explosive, present a numerical and material model, and offer a detailed numerical simulation of 
bridge behaviour when subjected to explosive action involving an equivalent of $1000 \mathrm{~kg}$ of TNT placed $0.5 \mathrm{~m}$ away from the pier and pylon, and $1.0 \mathrm{~m}$ away from the superstructure. The scope and mechanism of damage to piers, pylons and superstructure is analysed. In the following paper [21] the authors estimate the bridge damage and possibilities for its strengthening by CFRP (Carbon Fibre Reinforce Polymer) fibres. Yet another numerical method that can be used to simulate structural collapse [22-24] following an explosive action is the applied element method (AEM). This method differs from traditional finite-element methods in that the elements forming the structural segment or structure are in fact solid bodies interconnected with springs, which describe internal deformations and stress fields. Each AEM element surface is connected by its entire surface with another element via a set of springs, and each spring actually consists of 3 (or 6) springs with individual directions of freedom. The difference between FEM and AEM lies it that all deformations in FEM take place within the element, while all deformations within AEM occur outside of the element, i.e. in springs. Just like in FEM, AEM requires smaller finite elements for greater accuracy, but here it is easier to link the elements together as they are linked by external springs, rather than through nodes as in FEM [25]. The AEM is the only numerical method that can accurately analyse and visualise structural behaviour in all three loading phases: small and big deformations, and impact, or failure (collapse involving progressive failure). The only software that uses this calculation method is the Extreme Loading for Structures (ELS) [26].

If parameters related to the explosion and structure are adequately modelled, numerical simulations provide results that are quite close to experimental ones, although deviations can not be avoided. This is true not only for numerical models but also for experimental studies, which are also influenced by a considerable number of mostly external but also internal parameters [27-32].

\section{Numerical modelling}

Numerical models prepared for this research were developed using the Ansys Autodyn hydrocode software for dynamic analysis of fluids [12]. The program is based on the explicit theory of final differences involving the possibility of spatial problem modelling, and the calculation can be made using several distinct numerical formulations: Eulerian, Lagrange, Arbitrary Lagrange-Eulerian ALE, and Smoothed Particle Hydrodynamics, so as to optimise the analysis of nonlinear dynamic problems. The analysis must enable simulation of fluid behaviour (air) and structural behaviour, and their interactions [9].

The Lagrange formulation is used for modelling the solid continuum and structures, and it acts on the structured (I-J-K) numerical network of four-sided (2D) or square (3D) elements [33]. The finite element network moves and deforms simultaneously with the movement of material, and there is no transport of material between finite elements. The advantage of this formulation lies in accurate monitoring of the movement of material, and in precise definition of boundary between different materials, and the same applies to the boundary of different surfaces. The main disadvantage is that significant distortion of network elements occurs at considerable deformation of materials, which reduces the accuracy and efficiency of calculation, and can in some cases lead to divergence and interruption of calculation [34].

The Euler formulation is used for modelling fluids, gases and the related deformations, and this by applying the control volume method for solving equations of conservation of mass, quantity of motion, and energy. Unlike other techniques, the finite element network is fixed in space, and the material moves through the network. The advantage of this formulation lies in easy calculation of big deformations and movement of mass, but it is impossible to calculate the boundary between individual materials, and the boundary between different areas.

The Arbitrary Lagrange Euler (ALE) formulation of calculation is a hybrid method in which the finite element method moves and deforms in accordance with the user's specification. An additional step is added for moving the element network and copying solutions to the new network. The ALE is an extension to the Lagrangian formulation that combines best properties of both methods (Lagrangian and Eulerian).

The Ansys modelling based on explicit time integration is limited by the Courant-Friedrichs-Lewy condition [35]. The time step is limited so that the distortion (i.e. the stress) in the defined time step can not be extended by more than the lowest measure of a characteristic element defined by the finite element network. It follows that the time step for the stability of solution is determined according to (1):

$d t_{\mathrm{cou}}<\min \left(\frac{d x}{c}, \frac{d y}{c}\right)$

where:

$d t \quad$ - the time step

$d x, d y$ - characteristic values of the final element

c - the speed of sound in the material of the element under study.

Based on this condition, it can be concluded that the finer finite element network leads to the smaller time step and hence to the longer calculation time, and so the optimisation of the finite element network is one of key problems in numerical simulations.

\subsection{Overpass geometry and model}

The selected type of plate girder overpass measures $15 \mathrm{~m}$ in span and features a simple beam static system (Figure 1, left). The total width is $7.8 \mathrm{~m}$, and it consists of two traffic lanes each $3.0 \mathrm{~m}$ in width, and two sidewalks $0.9 \mathrm{~m}$ in width. The superstructure is $0.8 \mathrm{~m}$ in thickness at half span. The ends of the cross-section are formed of cantilevers $0.25 \mathrm{~m}$ in thickness. The clear height of the superstructure as related to the road passing under the overpass amounts to $5 \mathrm{~m}$. Two cross-section types are considered in this study (Figure 1, right). Non-typical rounded cross-section was selected as it is assumed that the rounded bottom of the 

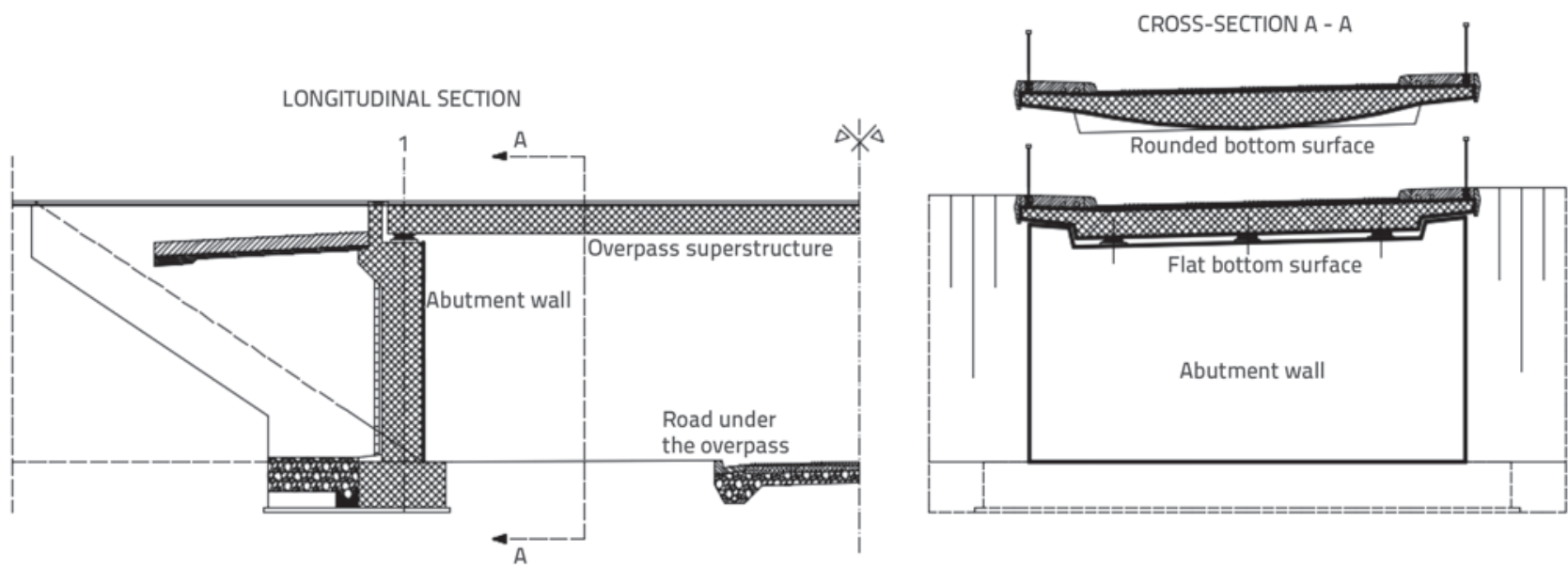

Figure 1. Overpass geometry (longitudinal and transverse cross section)

cross-section influences the resistance favourably by directly reducing the overpass area subjected to load. The explosion wave rebounds under a certain angle which means that an additional wave strengthening due to reflection does not occur, as would be the case for flat-bottom surface.

The superstructure is modelled as a reinforced concrete slab. Concrete elements are modelled with volumetric finite elements while bar finite elements are used for modelling reinforcement. Bar elements are placed within volumetric elements and are connected with them via body interaction that ensures joint behaviour when subjected to load. An ideal bonded contact between the concrete and reinforcement is assumed. The volumetric element is the type SOLID 186 20-node volumetric finite element (Figure 2).
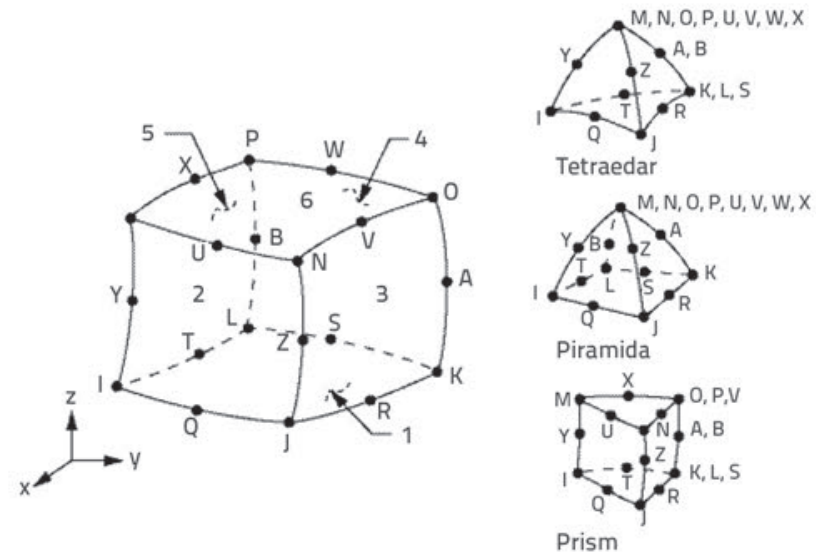

Figure 2. Volumetric element SOLID 186 [36]

This is a higher order element that can be used to model irregular shapes without reducing accuracy of results (compatible deformable shape appropriate for modelling curved edges). The element is defined with 20 points with three degrees of freedom, and with translations in $x, y$, and $z$ directions. It can have any spatial orientation and can be defined with plasticity, creep, strengthening, etc. The bar element is the type BEAM 189 2-node bar element (Figure 3). It is based on the Timoshenko theory and so the effects of transverse deformation are included in the calculation. The element is defined with two points with six degrees of freedom, and features translation in $x, y$ and $z$ directions, and rotation about the $x, y$, and $z$ axes. It is appropriate for linear and nonlinear calculations, and the crosssection is uniformly scaled as a function of longitudinal deformation during nonlinear analysis, so as to preserve volume of the element. It enables big deformations [12,36].

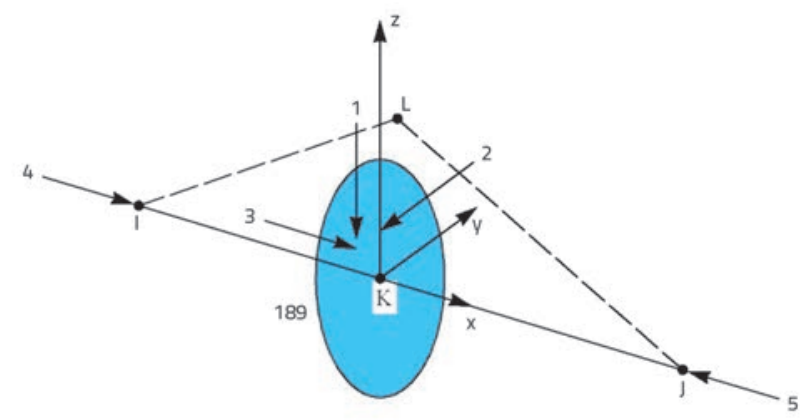

Figure 3. Bar element BEAM 189 [36]

The numerical model of the overpass consists of a part that is modelled as the Eulerian ideal gas (1 503684 volumetric elements) and of a structured part representing the overpass structure (RC slab 1620240 volumetric elements, reinforcement 23836 bar elements, and elastomeric bearing 384 volumetric elements). The mentioned number of elements is related to one fourth of the model. Soil is modelled by boundary condition that does not allow expansion of air particles in the explosion wave, nor expansion particles of eroded material of the overpass (concrete and steel). The explosion wave and structure interaction is calculated using the Euler-Lagrange interaction and erosion. The damage to superstructure is simulated by erosion, i.e. removal of damaged overpass material. Boundary conditions set for the remaining air zones enable free propagation of explosion wave pressure and eroded elements outside of the modelled air volume.

Figure 4 shows a spatial numerical model of an overpass with its surroundings. The modelling comprises the superstructure (of flat and, separately, of rounded cross-section), massive abutment, embankment, and detonation of explosive under the superstructure, while the entire model is situated in its environment where air characteristics are set (cf. Table 5). 
This part of the model is important, as this is the medium that transfers explosion wave pressure from the TNT explosive charge to the superstructure. Figure 5 shows the position of the explosion under the overpass. An already partly expanded explosion wave immediately before contact with the superstructure can be observed.

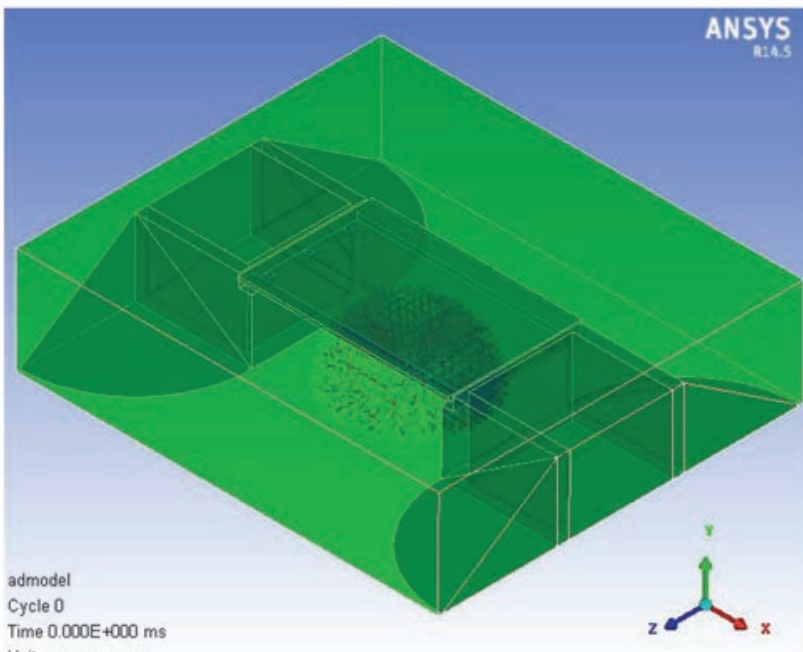

Units $\mathrm{mm}, \mathrm{mg}, \mathrm{ms}$

Figure 4. Overpass with massive abutment and its surroundings

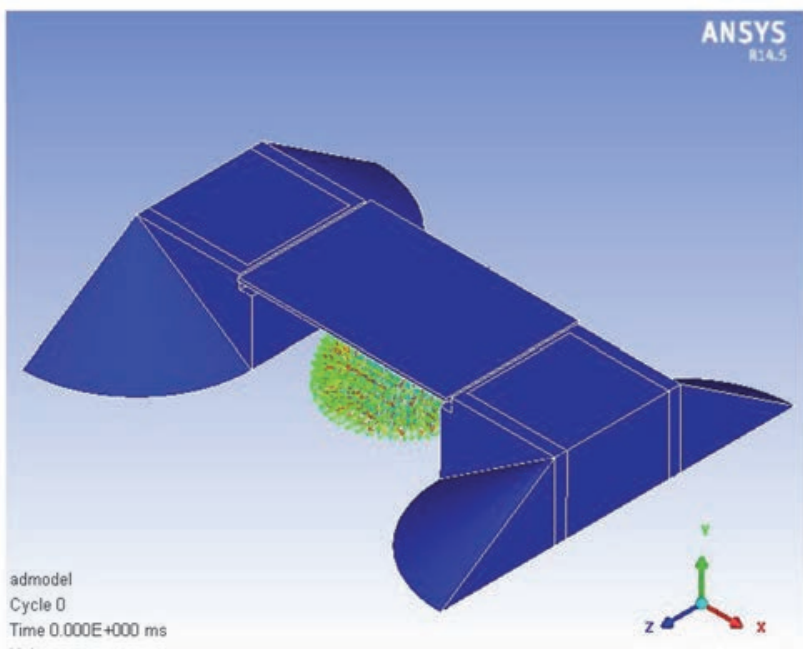

Figure 5. Start of explosion under the overpass

\subsection{Materials}

When selecting material properties, care must be taken to measure, in these cases, the time of action in milliseconds, which differs from properties for slow/static occurrences. The RHT (Riedel-HiermaierThoma) model was selected for concrete. This model has been experimentally determined on samples subjected to impulse load (impact), and it is considered to be sufficiently accurate for defining material behaviour during an explosion. Model parameters (Table 2) are adjusted to the concrete strength class C35/45 using factors proposed in [37,38], where a detailed description of the model can also be found.
Table 2. RHT model parameters for concrete class C35/45

\begin{tabular}{|c|c|c|}
\hline Parameter & Parameter description & $\begin{array}{c}\text { NSC, } 35[\mathrm{MPa}] \\
{[37.38]}\end{array}$ \\
\hline$G_{\mathrm{el}}$ & Elastic shear modulus & $16.7 \mathrm{GPa}$ \\
\hline$f_{\mathrm{c}}$ & $\begin{array}{l}\text { Static compressive strength of } \\
\text { concrete }\end{array}$ & $35.0 \mathrm{MPa}$ \\
\hline$f_{\mathrm{t}} / f_{\mathrm{c}}$ & $\begin{array}{l}\text { Ratio of static tensile to } \\
\text { compressive strength of concrete }\end{array}$ & 0.10 \\
\hline$f_{\mathrm{s}} / f_{\mathrm{c}}$ & $\begin{array}{l}\text { Ratio of shear strength to static } \\
\text { compressive strength of concrete }\end{array}$ & 0.18 \\
\hline$A_{\text {fail }}$ & $\begin{array}{l}\text { Pressure independent parameter } \\
\text { for failure surface }\end{array}$ & 0.00 \\
\hline$B_{\text {fail }}$ & Linear parameter for failure surface & 1.60 \\
\hline$N_{\text {fail }}$ & Failure surface index & 0.61 \\
\hline$Q_{2.0}$ & $\begin{array}{l}\text { Ratio of tensile to compressive } \\
\text { meridian. reference value }\end{array}$ & 0.6805 \\
\hline$B Q$ & $\begin{array}{l}\text { Parameter of transfer from brittle } \\
\text { to ductile behaviour }\end{array}$ & 0.0105 \\
\hline$G_{\mathrm{el}} /\left(G_{\mathrm{el}}-G_{\mathrm{pl}}\right)$ & $\begin{array}{c}\text { Ratio of elastic shear modulus to } \\
\text { the difference between elastic and } \\
\text { plastic shear modulus }\end{array}$ & 2.0 \\
\hline$f_{\text {t.el }} / f_{\mathrm{t}}$ & $\begin{array}{l}\text { Ratio of elastic to static tensile } \\
\text { strength of concrete }\end{array}$ & 0.70 \\
\hline$f_{\text {c.el }} / f_{c}$ & $\begin{array}{l}\text { Ratio of elastic to static } \\
\text { compressive strength of concrete }\end{array}$ & 0.53 \\
\hline Cap option & Peak value option & Active \\
\hline$B_{\text {fric }}$ & $\begin{array}{l}\text { Linear parameter for residual } \\
\text { strength surface }\end{array}$ & 1.60 \\
\hline$N_{\text {fric }}$ & Residual strength surface index & 0.61 \\
\hline$\alpha$ & $\begin{array}{l}\text { Index of compressive strength } \\
\text { increment }\end{array}$ & 0.032 \\
\hline$\delta$ & Index of tensile strength increment & 0.036 \\
\hline$D_{\mathrm{RHT} 1}$ & D1 material damage parameter & 0.04 \\
\hline$D_{\mathrm{RHT2}}$ & D2 material damage parameter & 1.00 \\
\hline$\varepsilon_{\min }^{\text {failure }}$ & Minimum deformation at failure & 0.01 \\
\hline ShratD & Part of residual shear modulus & 0.13 \\
\hline
\end{tabular}

Table 3. Concrete failure parameters

\begin{tabular}{|c|c|c|}
\hline Parameter & Value & Unit \\
\hline Failure & RHT concrete & $/$ \\
\hline D1 & 0.04 & $/$ \\
\hline D2 & 1.00 & $/$ \\
\hline Minimum deformation at failure & 0.01 & $/$ \\
\hline Residual part of elastic shear modulus & 0.13 & $/$ \\
\hline Tensile failure & principal & $/$ \\
\hline stress & 3290 & $\mathrm{kPa}$ \\
\hline Principal tensile stress at failure & Da & $/$ \\
\hline Cracking & 100 & $\mathrm{~J} / \mathrm{m}^{2}$ \\
\hline Stochastic failure & $\mathrm{Ne}$ & $/$ \\
\hline
\end{tabular}


Table 4. Static and dynamic parameters of selected reinforcement B500B

\begin{tabular}{|c|c|c|c|c|}
\hline B500B & $E\left[N / \mathrm{mm}^{2}\right]$ & $f_{\mathrm{y}}\left[\mathrm{N} / \mathrm{mm}^{2}\right]$ & $\varepsilon_{\mathrm{y}}[\%]$ & $f_{u}\left[\mathrm{~N} / \mathrm{mm}^{2}\right]$ \\
\hline Static & 210000 & 500 & 0.238 & 540 \\
\hline Dynamic & 210000 & 755 & 0.238 & 615.6 \\
\hline
\end{tabular}

In addition to basic concrete strength parameters, the model also includes simulation of material failure at the tensile strength limit. Concrete failure parameters are shown in Table 3. The dynamic increase factor has not been additionally applied to the concrete model [39], as the model has been developed specifically for dynamic actions.

A bilinear kinematic elastoplastic model was selected for reinforcement. The reinforcement quality B500B was selected. The DIF was applied to static values so as to simulate dynamic behaviour of reinforcement. Considering the estimated reinforcement deformation speed at the explosion of $1000 \mathrm{~s}^{-1}$, the DIF presented in [40] amounting to 1.51 was applied for the yield limit, while the value of 1.14 was applied for tensile strength. The calculated dynamic properties of reinforcement are given in Table 4. The air was modelled using the equation of state for an ideal gas, in which the pressure $p$ is related to energy via the empirical expression (2):

$p=(\gamma-1) \rho e$

where:

$\rho$ - the air density

$e$ - the specific internal energy

$\gamma$ - the constant.

This equation is one of the simplest equations of state. Air is a gaseous material and so there is no possibility of stress transfer. Thus, air is not influenced by any change of strength or failure principle, and serves solely as a medium that transfers impact waves generated by detonation. Principal air parameters used in numerical model are given in Table 5.

Table 5. Material properties of air

\begin{tabular}{|c|c|c|}
\hline \multicolumn{3}{|c|}{ Zrak } \\
\hline Equation of state & Ideal gas & \\
\hline Reference density & $1.225 \cdot 10^{-3}$ & {$\left[\mathrm{~g} / \mathrm{cm}^{3}\right]$} \\
\hline$\Gamma$ & 1.40 & \\
\hline Reference temperature & 288.20 & {$[\mathrm{~K}]$} \\
\hline Specific heat & 717.60 & {$[\mathrm{~J} / \mathrm{kgK}]$} \\
\hline Initial energy & $2.068 \cdot 10^{5}$ & {$[\mathrm{~mJ} / \mathrm{mg}]$} \\
\hline
\end{tabular}

Detonation is a process in which the explosive material converts into gas, and this process most often ends at the very beginning of simulation. Similar to air, explosive material does not have any strength nor is it susceptible to failure. Explosive is modelled with the Jones-Wilkins-Lee (JWL) [41] equation of state (3):
$p=A\left(1-\frac{\omega}{R_{1} \chi}\right) e^{-R_{1} \chi}+B\left(1-\frac{\omega}{R_{2} \chi}\right) e^{-R_{2} \chi}+\frac{\omega}{\chi}$

where:

$p$ - the hydrostatic pressure

$\chi$ - the specific volume $(1 / \rho)$

$e$ - the specific internal energy

$A, R_{1}, B, R_{2}, \omega$ - constants determined by experiment [42].

TNT parameters used in numerical model are presented in Table 6.

Table 6. Material properties of TNT

\begin{tabular}{|c|c|c|}
\hline \multicolumn{3}{|c|}{ TNT } \\
\hline Equation of state & JWL & \\
\hline Reference density & 1.63 & {$\left[\mathrm{~g} / \mathrm{cm}^{3}\right]$} \\
\hline Parameter $A$ & $3.738 \cdot 10^{8}$ & {$[\mathrm{kPa}]$} \\
\hline Parameter $B$ & $3.747 \cdot 10^{6}$ & {$[\mathrm{kPa}]$} \\
\hline Parameter $\mathrm{R}_{1}$ & 4.15 & \\
\hline Parameter $\mathrm{R}_{2}$ & 0.90 & \\
\hline Parameter $\omega$ & 0.35 & \\
\hline C-J detonation speed & $6.930 \cdot 10^{3}$ & {$[\mathrm{~m} / \mathrm{s}]$} \\
\hline C-Jenergy per unit of volume & $6.000 \cdot 10^{6}$ & {$\left[\mathrm{~kJ} / \mathrm{m}^{3}\right]$} \\
\hline C-Jpressure & $2.100 \cdot 10^{7}$ & {$[\mathrm{kPa}]$} \\
\hline Initial energy & $3.681 \cdot 10^{6}$ & {$[\mathrm{~mJ} / \mathrm{mg}]$} \\
\hline
\end{tabular}

\subsection{Finite-element mesh}

Due to very brief period of explosion wave action, and to rapid transfer of energy between elements, numerical results on wave propagation and interaction with the structure are highly sensitive to the size of the finite element mesh. In addition, an uneven distribution of pressures caused by explosion at various mesh values creates pressure gradients that can differ to a great extent [43].

According to studies presented in $[4,10,39,43-48]$ the finiteelement mesh acceptable for one case of explosive action does not have to be relevant for any other case, although the problems treated are quite similar. It can therefore be stated that a simple verification of mesh size convergence does not have to be sufficient for guaranteeing accurate numerical results. The mesh of elements that is sufficiently accurate to estimate excess pressure generated by explosion over great distances may be overly general for estimating cases where distances are small. Furthermore, due to computing power and software limitations, it is sometimes impossible to use a small 
mesh of elements in simulations. In such cases, it is necessary to use less sensitive meshes, which inevitably leads to errors.

Due to nonlinearity of the explosion-caused bridge damage process, numerical model parameters, i.e. time step and finiteelement size, must be calibrated with experimental data. Unlike elastic problems where a finer element mesh and a smaller time step provide more accurate results, this is not necessarily the case when dealing with nonlinear problems. In fact, reduction of mesh elements and time step does not necessarily lead to more accurate results as these results also depend on material characteristics. In addition, an extremely fine mesh may cause numerical instabilities.

As experimental data on the effect of explosions on bridges are not readily accessible, the model element mesh can be calibrated using experimental data for other components made using similar materials. Although this process does not ensure full accuracy of the calibrated model, the results will nevertheless be more accurate that those that are solely based on parametric analysis of the model.

Consequently, the model was calibrated, i.e. an optimum finite element mesh was determined, by comparing simulation results with experimental results of the effect of explosive action on a RC slab, as conducted by Zhao et al. [49]. The comparison of experimental and numerical model results related to damage propagation revealed a good correspondence of results for the mesh element size of $25 \mathrm{~mm}$. The level of damage is slightly higher in numerical models compared to experimental testing because of real and numerical boundary conditions and difference between the real and modelled behaviour of materials. In fact, the numerically set boundary condition exhibits an absolute stiffness (fixity), while only nominal fixity can be realized under experimental conditions, and the actual behaviour of material is much more complex compared to the simplified model-based behaviour. The mentioned mesh size was applied to all elements of the numerical model: superstructure and air.

\subsection{Parallel analysis}

The Autodyn software was developed specifically for the analysis of nonlinear dynamic problems such as impacts or explosive actions on structures or their components. The complexity of the problems to be solved actually increases with an increase in reliability of computer simulations. However, practical application of large-size simulations is limited by reduced capacities of the existing computers. It is not unusual that an analysis with the model consisting of several millions of elements can take as long as several weeks. The use of parallel analysis is the only approach that is capable of solving this problem. Parallel algorithms were introduced in Autodyn so as to make use of the possibilities of parallel analysis enabling simultaneous use of several computer processors either in the scope of a network consisting of several computers, or within a single computer. The decomposition of the domain (model) is used for shaping the parallel analysis of both structured (Lagrange) and unstructured (Euler) parts. In this method, each part is divided so as to create smaller parts, subdomains. Subdomains are further distributed between central processing units (CPUs). Each subdomain is analysed in the scope of a parallel analysis as if it were a standard part of a serial analysis. The algorithm also enables decomposition of complex Euler/ Lagrange models [50].

Considering the complexity of the problem, the decomposition was made automatically, i.e. the Autodyn was allowed to do the model decomposition based on internal algorithm that attempts to reduce communication between processors to minimum, and to harmonize their load. Only the number of tasks, i.e. processors to be used in the analysis, was set, which is determined on the basis of the HPC licence allowing simultaneous use of 8 processors. The overpass model decomposition is shown in Figure 6.

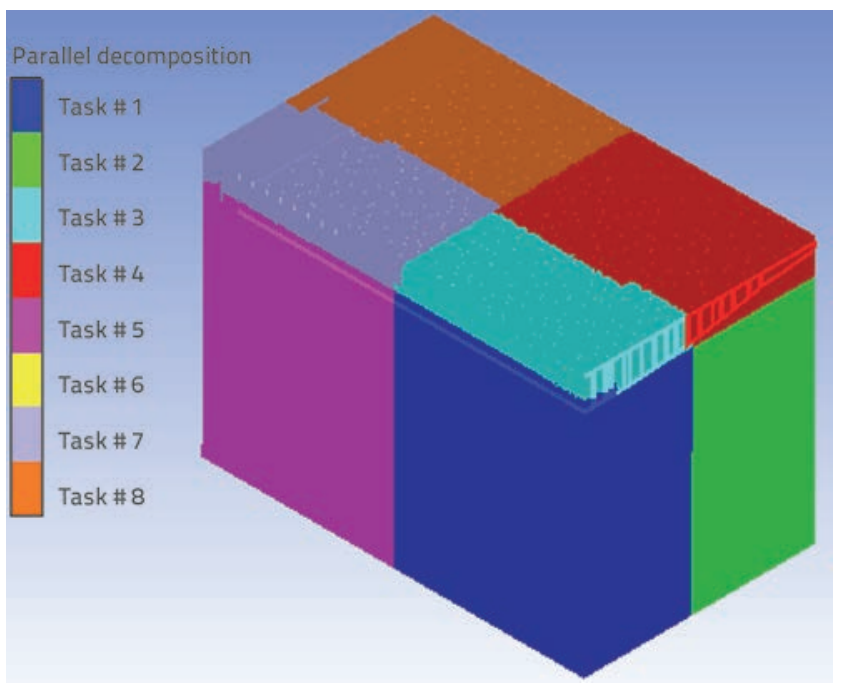

Figure 6. Overpass decomposition

\section{Results and discussion}

The analysis focuses on the propagation of explosion waves and interaction with the superstructure. The wave pressure surface acting on the superstructure has been designed, and the resulting damage is visually presented. The stress in reinforcement is presented, as well as the form of cracks generated by the wave pressure action, and the erosion of the superstructure forming material, concrete. The results are related to the moment of the maximum explosion pressure action (1.5 ms).

In the first part of the analysis, the overpass model was assumed to be (and modelled as) an absolutely stiff structure for which only the explosion wave propagation and acting pressure values were observed. The structure was regarded as being absolutely stiff so as to speed up the analysis and eliminate all other effects of pressure, i.e. damage to the superstructure. Thus the analysis was restricted to pressure values only, i.e. to the load exerted onto the superstructure due to detonation of an explosive charge placed under the overpass. A smaller quantity of explosive was used in this case (100 kg of spherically shaped TNT explosive) as related to damage simulation where a greater quantity was used, so as 
to correspond to real capacities of vehicles operating under the overpass. Regardless of the quantity of explosive, the way in which waves propagated, and the distribution of pressure on the superstructure, remained the same for the similar shape of explosive charge and for similar detonation point, and so the variation of quantity of explosives resulted only in variation of the acting pressures.

In the second phase, the overpass superstructure was modelled as a deformable structure, and the analysis also involved material properties of concrete and steel, so as to simulate the damage. Only one fourth of the structure, with the use of symmetry about the longitudinal and transverse axes, was modelled in this phase. This additionally reduced the analysis time, without affecting the accuracy of results. The overpass was analysed for the first three quantities of explosive $(115 \mathrm{~kg}, 230$ $\mathrm{kg}$, and $680 \mathrm{~kg}$ ) indicated in Table 1, which are assumed to be the most probable in real-life scenarios. Damage results are presented for the greatest quantity of explosive only (680 kg of TNT).

\subsection{Propagation of explosion waves and load exerted on overpass superstructure}

The propagation of explosion waves is operated in accordance with their assumed shape. In fact, waves propagate in form of concentric circles from the centre (source) of detonation toward outside, creating the initial pressure. The wave propagates until contact with the superstructure, after which the wave particles rebound from the superstructure surface. After rebound, wave particles collide with other oncoming particles causing pressure, which in turn causes an increase in pressure exerted on the observed surface, and so the rebound pressure occurs. The wave impact, pressurizing, and increase in wave pressure, can be seen in Figure 7, as a darkred colouring in wave contours (a1, b1, a2, b2, a3, b3, b4, c4). The wave continues to propagate and overflows the superstructure edges, which also causes pressure on the top surface of the superstructure (Figure 7; a4, a5, a6). The wave also reaches the abutment and exerts pressure on its wall,
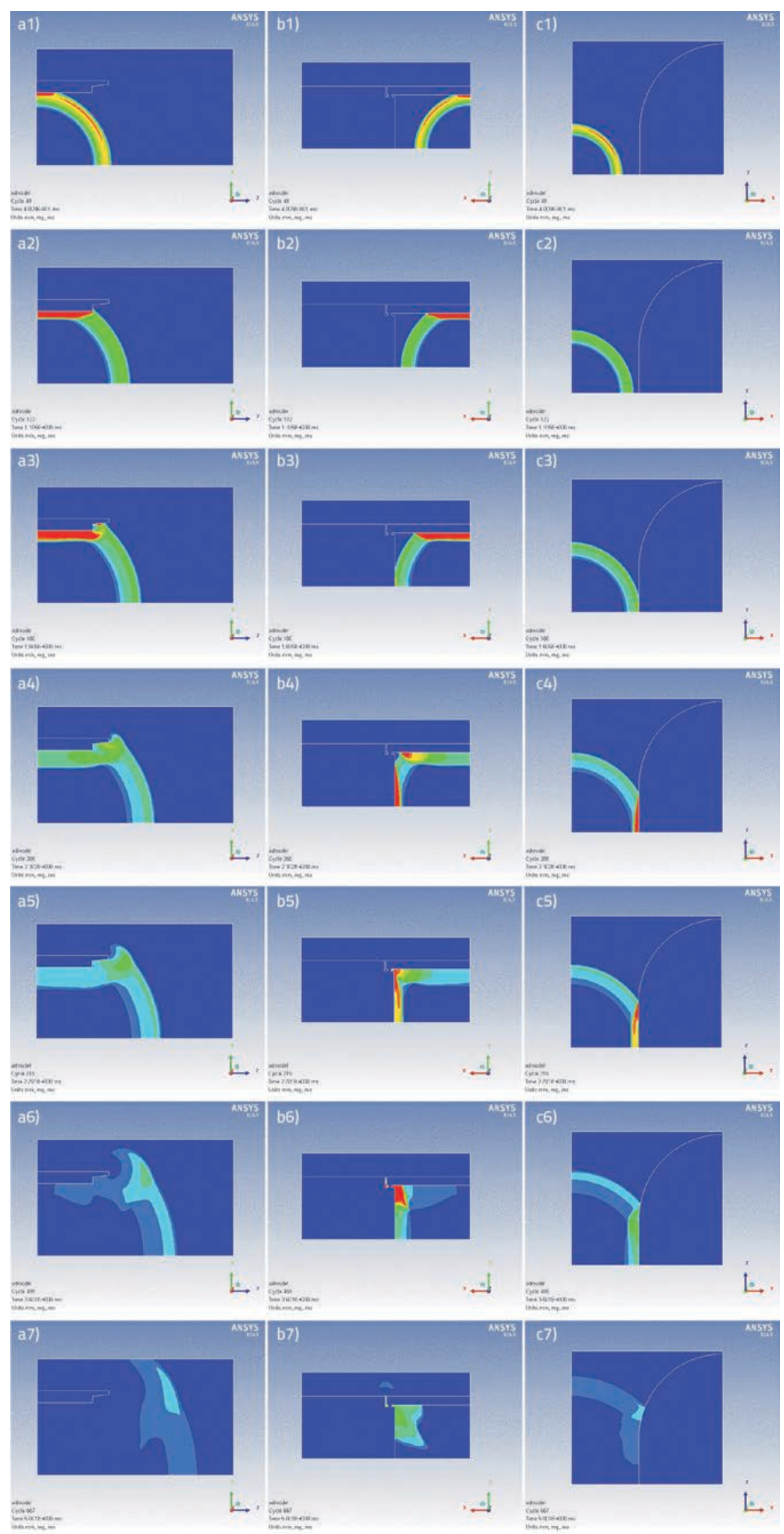

Figure 7. Propagation of wave front around the overpass over several time segments (column a: around cross-section of the superstructure; column b: at the support; column c: in plan, around abutment wall) 
but here the pressure value is lower as the abutment wall is farther away from the detonation point as compared to the superstructure. After the wave collides with the superstructure and abutment, the resulting rebounded wave travels along the surface toward the bearing seat (Figure 7; b4, b5, b6, b7). If a sufficient quantity of explosive is detonated this can cause higher pressures at the edges of the superstructure, which may consequently provoke lifting and sliding from the bearing seat. As there is a free space between the superstructure and the abutment, the bearings enable "ventilation" i.e. partial passage of explosion wave, which reduces

the final pressure at the end of the overpass (Figure 7; b6, b7)..

Detonation is in most cases followed by a "fireball" that is created because the explosive device mixture (gas, chemical, explosive) is so concentrated that the entire quantity of material can not detonate at the same time, but burns over time. The action of this "fireball" on the structure can result in damage greater than in the case of an ordinary explosive action. However, the diameter and duration of this "ball" are very hard to define as the activity does not stop suddenly but through gradual cooling. In addition, the "fireball" is in most cases optically dense and so it is impossible to properly determine which processes take place within the "ball". In addition, relevant measurements are very scarce as catastrophic explosions are most often unannounced and no preparations can be made for their measurement. If the risk of explosion effects is compared to the risk of "fireball" effect, it can be seen that the "fireball" action has a greater effect on persons at greater distances compared to explosive action. Conversely, structures are more affected by explosion at greater distances compared to "fireball" action [51]. For these reasons, the effects of "fireball" are not taken into account in the analysis of explosive action on the overpass.

The pressure envelope is obtained by setting measurement points at regular intervals of the bottom surface. These points are used to measure pressure rebound after contact with the superstructure, over time. Starting from the centre of the superstructure, these points are placed at $0.5 \mathrm{~m}$ intervals in longitudinal direction, and at $0.39 \mathrm{~m}$ in transverse direction, and thus a uniform network

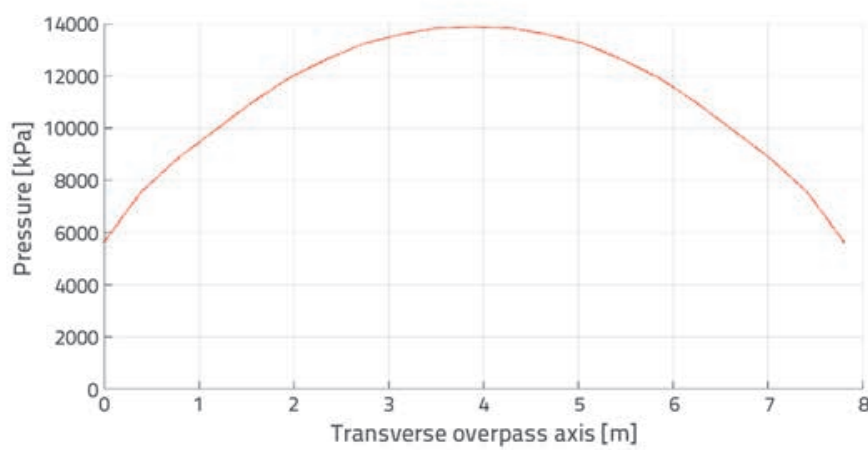

Figure 9. Distribution of explosion pressures along the overpass width and length

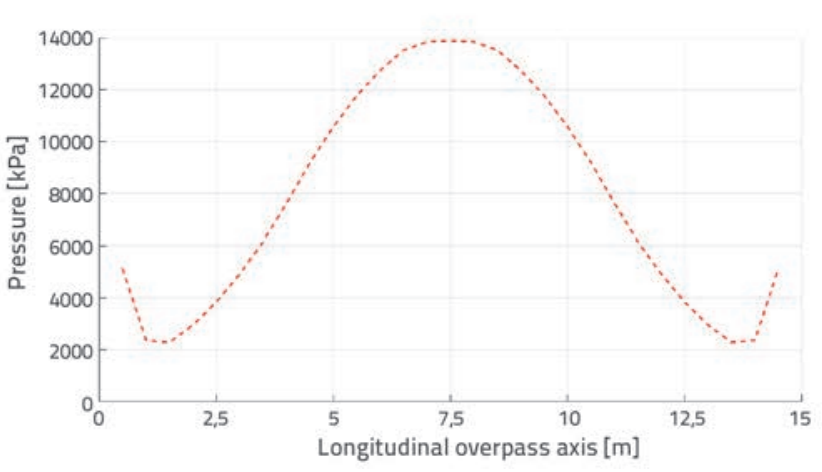

consisting of 609 measurement points is obtained. The surface of pressures acting on the underside of the superstructure is created based on time records of pressures registered at each point. The resulting envelope of maximum pressures is presented in Figure 8. Figure 9 shows distribution of maximum pressures along the width and length of the overpass, in the central axis. The maximum wave action is in the centre of the span as this point of the overpass is the closest to the detonation point. It can be observed that the pressure values reduce as the distance from the centre of detonation increases. By analysing the change of pressure in longitudinal direction, it can be seen that the pressures reduce toward the end of the overpass, although a new increase in pressure is registered at the overpass ends, which is caused by additional impact of waves rebounding from the superstructure and abutment wall (Figure 7; b5, b6). Generally, both cross-section types, flat and rounded, have a similar form of the maximum pressure envelope.

\subsection{Damage to superstructure}

The analysis of results with visualisation of infrastructure damage reveals that the top surface suffered much greater damage compared to the bottom surface. Figure 10 shows distribution of cracks on the top surface of the superstructure at the moment of maximum pressures, for both types of cross section: flat (left) and rounded (right). The distribution of cracks at the bottom surface is shown in Figure 11. 

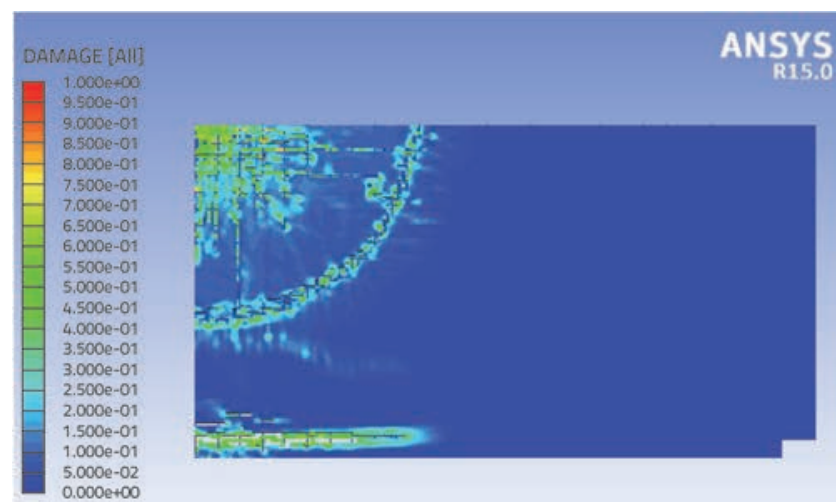

Cycle 989

Time 1.481E $+000 \mathrm{~ms}$

Units $\mathrm{mm}, \mathrm{mg}, \mathrm{ms}$
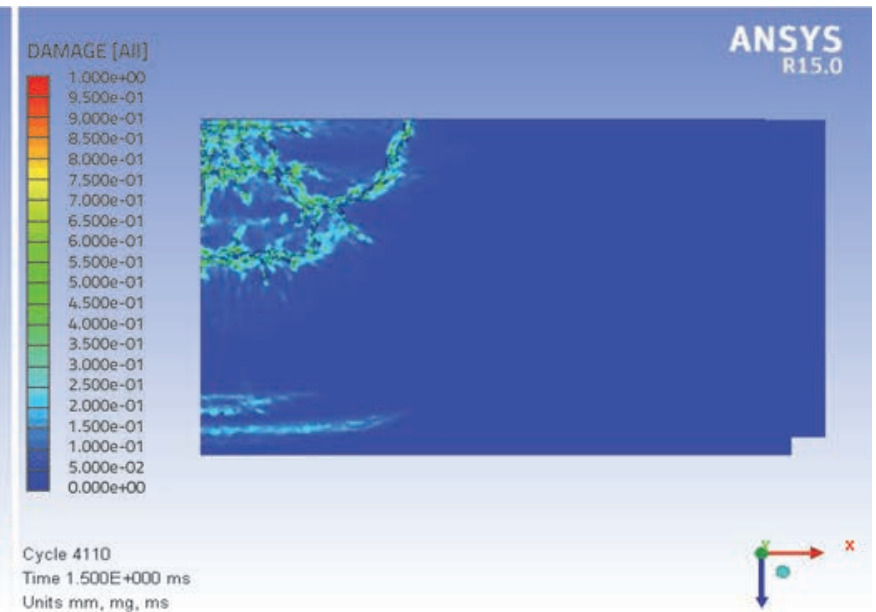

Cycle 4110

Time $1.500 \mathrm{E}+000 \mathrm{~ms}$

Units $\mathrm{mm}, \mathrm{mg}, \mathrm{ms}$

Figure 10. Superstructure damage in $\mathrm{t}=\mathbf{1 . 5} \mathrm{ms}-$ top surface

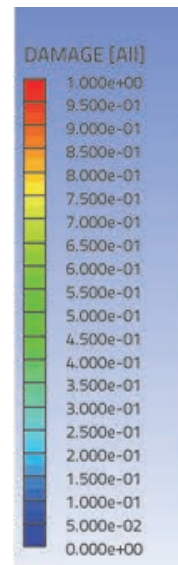

Cycle 989

Time 1.481E+000 ms

Units $\mathrm{mm}, \mathrm{mg}, \mathrm{ms}$

Figure 11. Superstructure damage in $\mathrm{t}=\mathbf{1 . 5} \mathrm{ms}$ - bottom surface

The damage starts within the cross-section, i.e. in the crosssection core, and spreads toward the top surface, while the bottom surface remains almost undamaged at the point of explosion wave
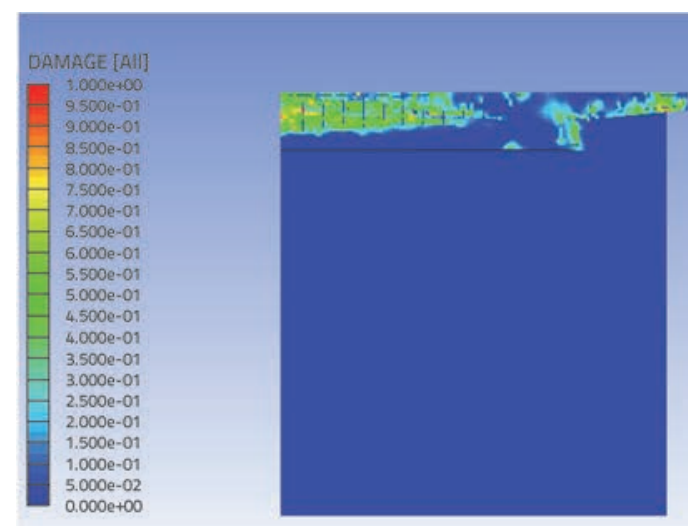

Cycle 989

Time $1.481 \mathrm{E}+000 \mathrm{~ms}$

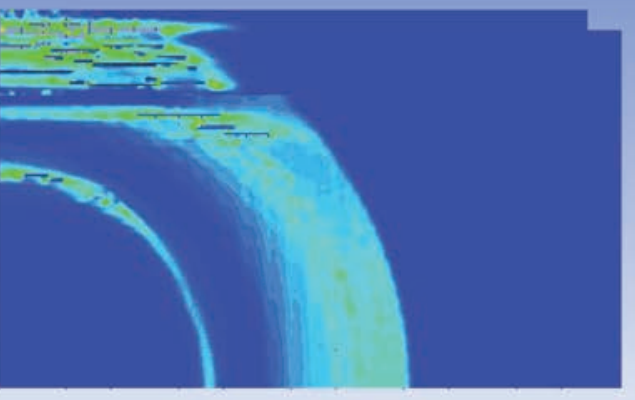

z

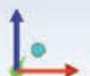

$x$

Time $1.500 \mathrm{E}+000 \mathrm{~ms}$

Units $\mathrm{mm}, \mathrm{mg}, \mathrm{ms}$

action. This can clearly be seen at the cross-section (Figure 12) and longitudinal section of the superstructure (Figure 13). In addition to slab damage, the damage is also registered at cantilevers. Once

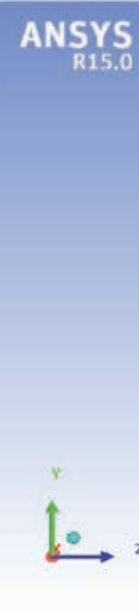

ANSYS

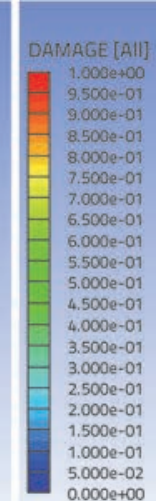

Time $1.500 \mathrm{E}+000 \mathrm{~ms}$

Units $\mathrm{mm}, \mathrm{mg}, \mathrm{ms}$

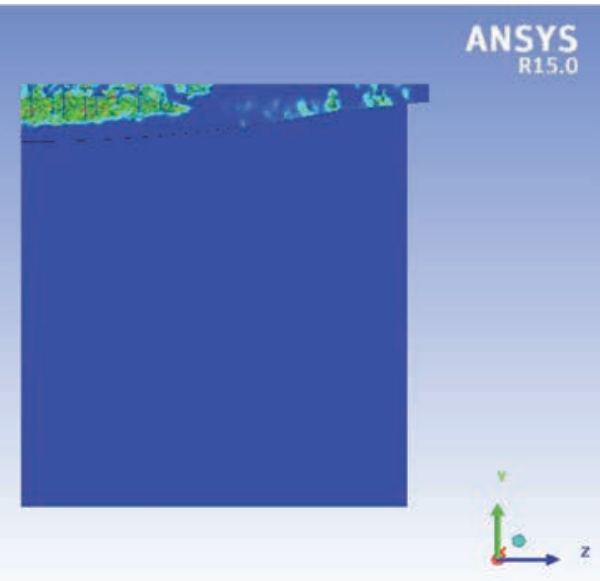

Units $\mathrm{mm}, \mathrm{mg}, \mathrm{ms}$

Figure 12. Superstructure damage in $t=1,5 \mathrm{~ms}-$ cross-section 
again, the damage is greater in case of the superstructure with flat bottom surface. Smaller damage to rounded cantilever is due to a gradual increase in pressure as the wave slides along the rounded surface of the slab and cantilever, while in case of flat cross-section, there is a sudden rebound and compression of pressure particles after collision with the flat surface (Figure 11 and Figure 12).

The stress registered within the superstructure reinforcement reveals that structural reinforcement from the top zone of the superstructure participates the most in the transfer of load caused by explosion. The principal reinforcement, obtained by dimensioning the structure to standard permanent and variable loads, has only a minor influence on the resistance of the cross-section, as most of the resistance is achieved by means of structural reinforcement. It can therefore be concluded that double reinforcement of the superstructure can greatly contribute to its resistance to explosive action. During reinforcement of the superstructure, the use can be made of the principle involving reinforcement of seismically resistant piers, in which reinforcement obtained by dimensioning is placed in both zones (compressive and tensile) of the pier.

The condition of superstructure material is shown in Figure 15. The previously described damage to the top surface and

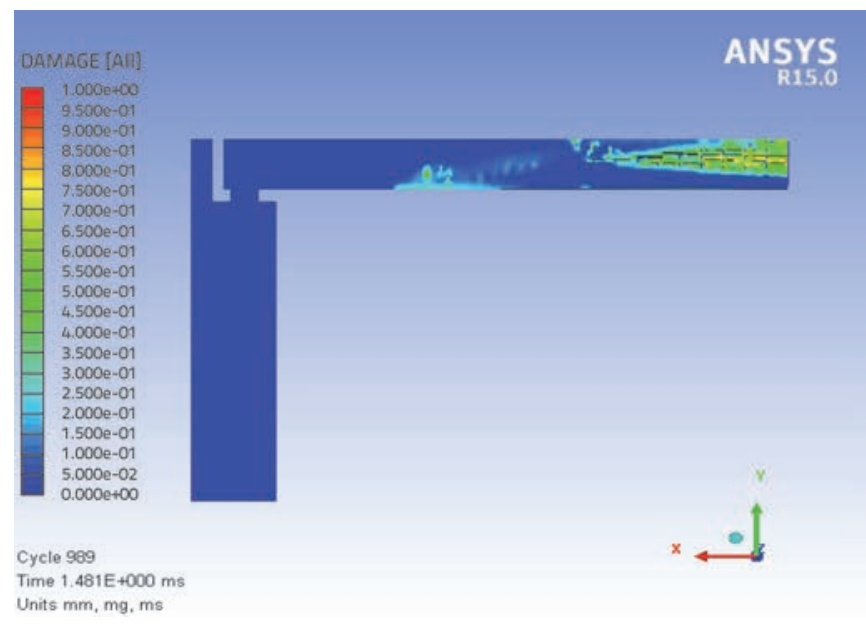

Figure 13. Superstructure damage in $\mathrm{t}=1,5 \mathrm{~ms}-$ longitudinal section
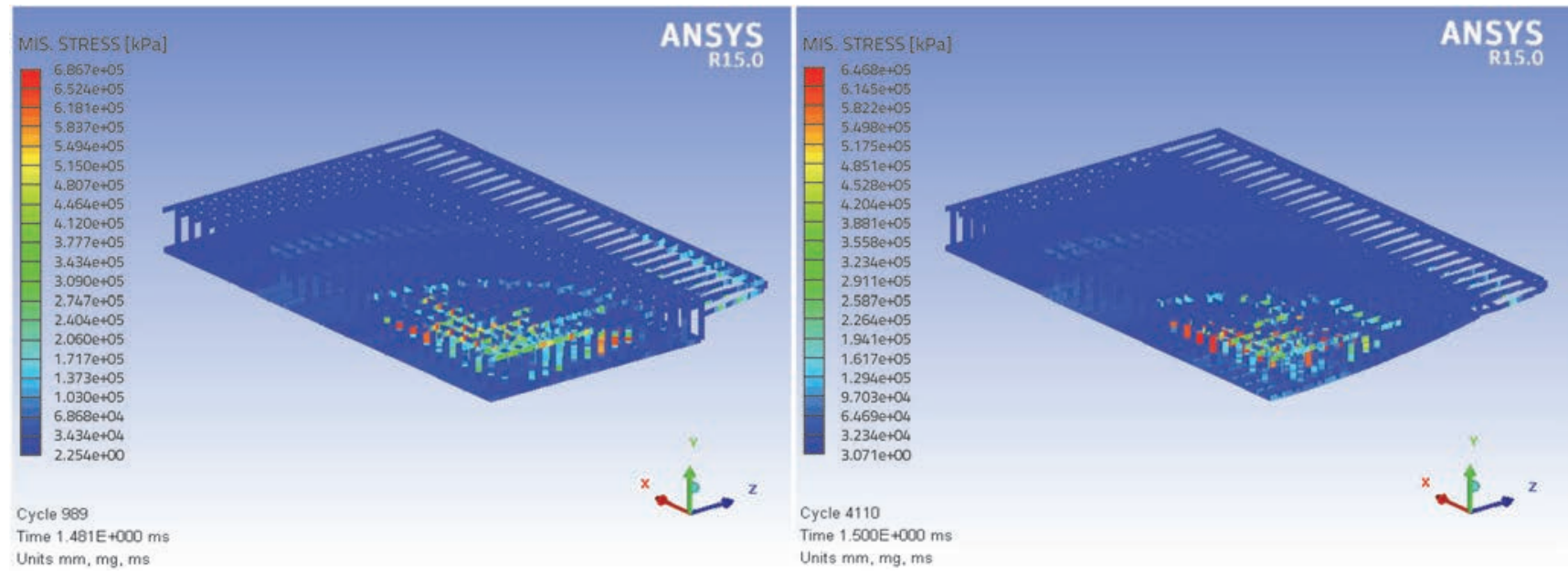

core of cross-section, where failure has occurred, can be observed. The compressive deformation of concrete exceeds the limit of $3.5 \%$ at the bottom edge of cross-section, wile the tensile strength of $3.2 \mathrm{~N} / \mathrm{mm}^{2}$ is exceeded at the top edge. The remaining parts of the superstructure still exhibit elastic behaviour and it is especially interesting to note that the bottom surface of the superstructure, which is directly affected by explosion wave action, also exhibits elastic behaviour, i.e. the plastic deformation has not occurred. The extent of damage to superstructure can clearly be seen if damaged elements, i.e. elements where deformation is much greater than the defined limit, are removed from the model (Figure 16).

\subsection{Overpass condition assessment based on pressure-impulse diagrams}

The duration of load generated by explosion is very brief. It depends on the quantity of explosive charge and distance from the structure, e.g. for $100 \mathrm{~kg}$ of TNT placed at the distance of $1 \mathrm{~m}$ the positive phase lasts about $1.2 \mathrm{~ms}$, while for the distance of 10 $\mathrm{m}$ the positive phase lasts about $11 \mathrm{~ms}$. The load ends when the

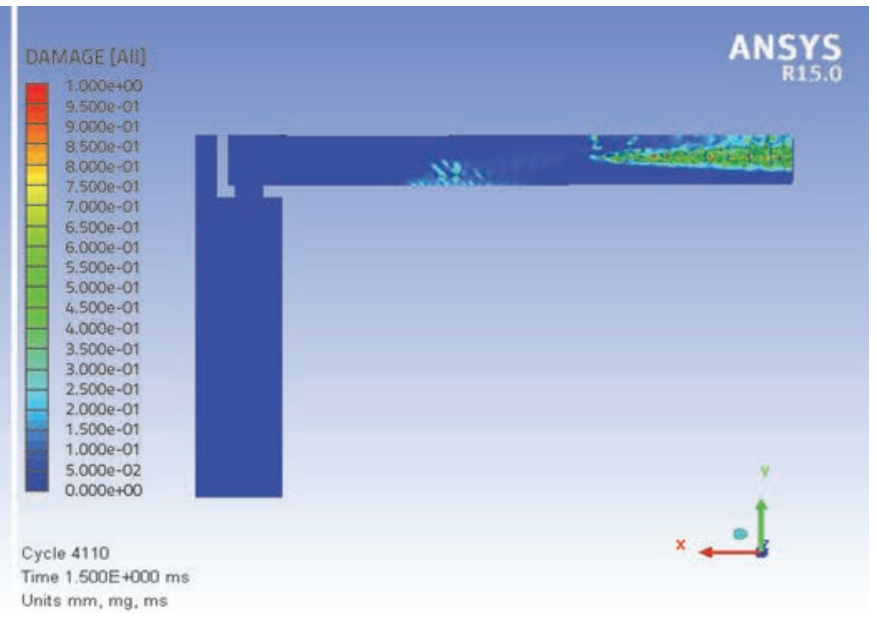

Figure 14. Von Mises stress for superstructure in $t=1,5 \mathrm{~ms}$ 


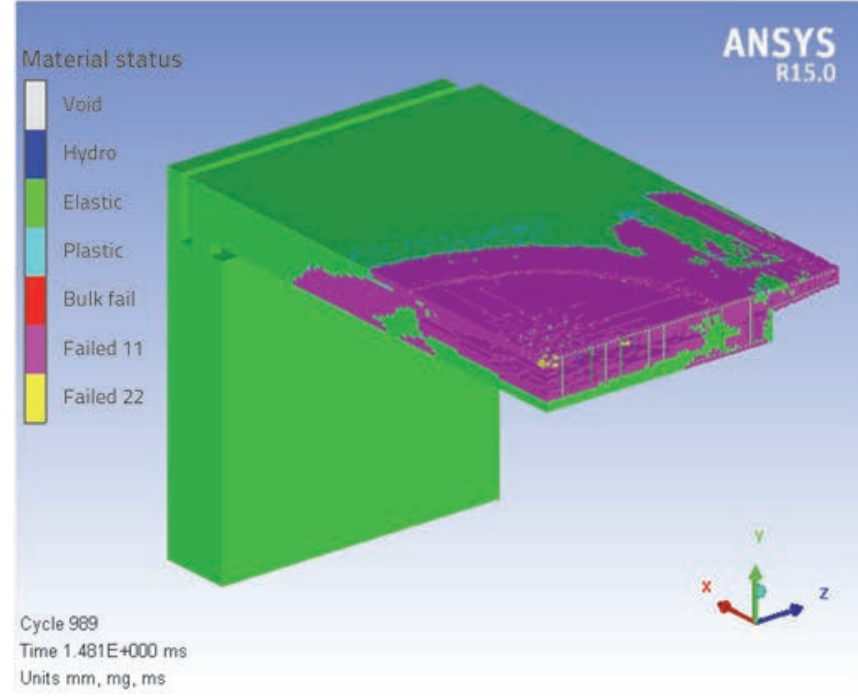

Figure 15. Condition of material in $t=1,5 \mathrm{~ms}$

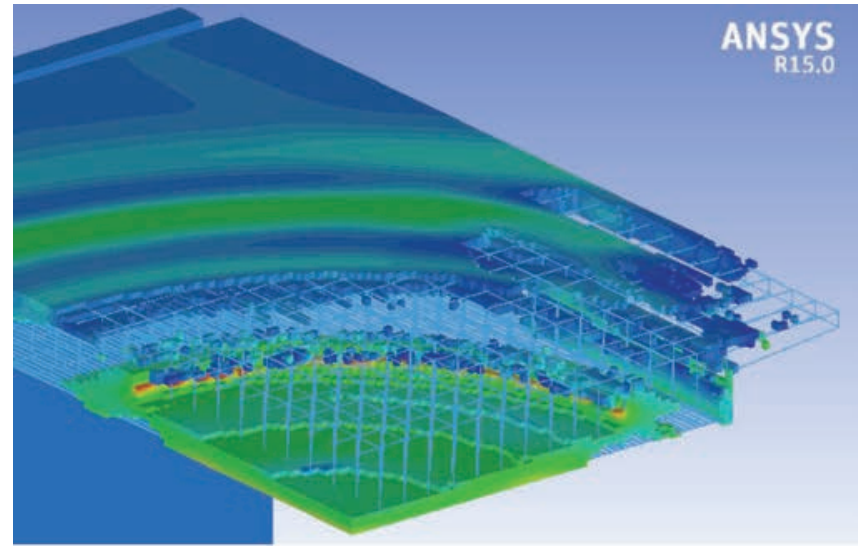

Figure 16. Superstructure damage

mass moves, i.e. when the response of the structure is reduced. Explosion parameters, pressure and impulse, can be used as a means to represent any load caused by explosion. For structures exposed to explosive action, the pressure-impulse diagrams are isobaric curves that represent levels of structural damage for individual pressure and impulse combinations [52, 53]. The pressure-impulse $(P-I)$ diagram is a tool enabling simplified estimation of behaviour of a structural element exposed to some load, which is explosive load in the case under study. When a designer defines the maximum value of a specific response parameter, the diagram is the pressure and impulse combination that will cause an equal level of damage to the element under study [54]. Each pressure-impulse diagram consists of two asymptotes: impulse and pressure. The impulse asymptote is related to the load of very short duration as related to natural frequency of the structure, and it represents the minimum impulse needed to achieve a certain level of damage. On the other had, the pressure asymptote is related to longer lasting loads as compared to natural frequency of the structure. In this range, the structure becomes insensitive to impulse action and sensitive to
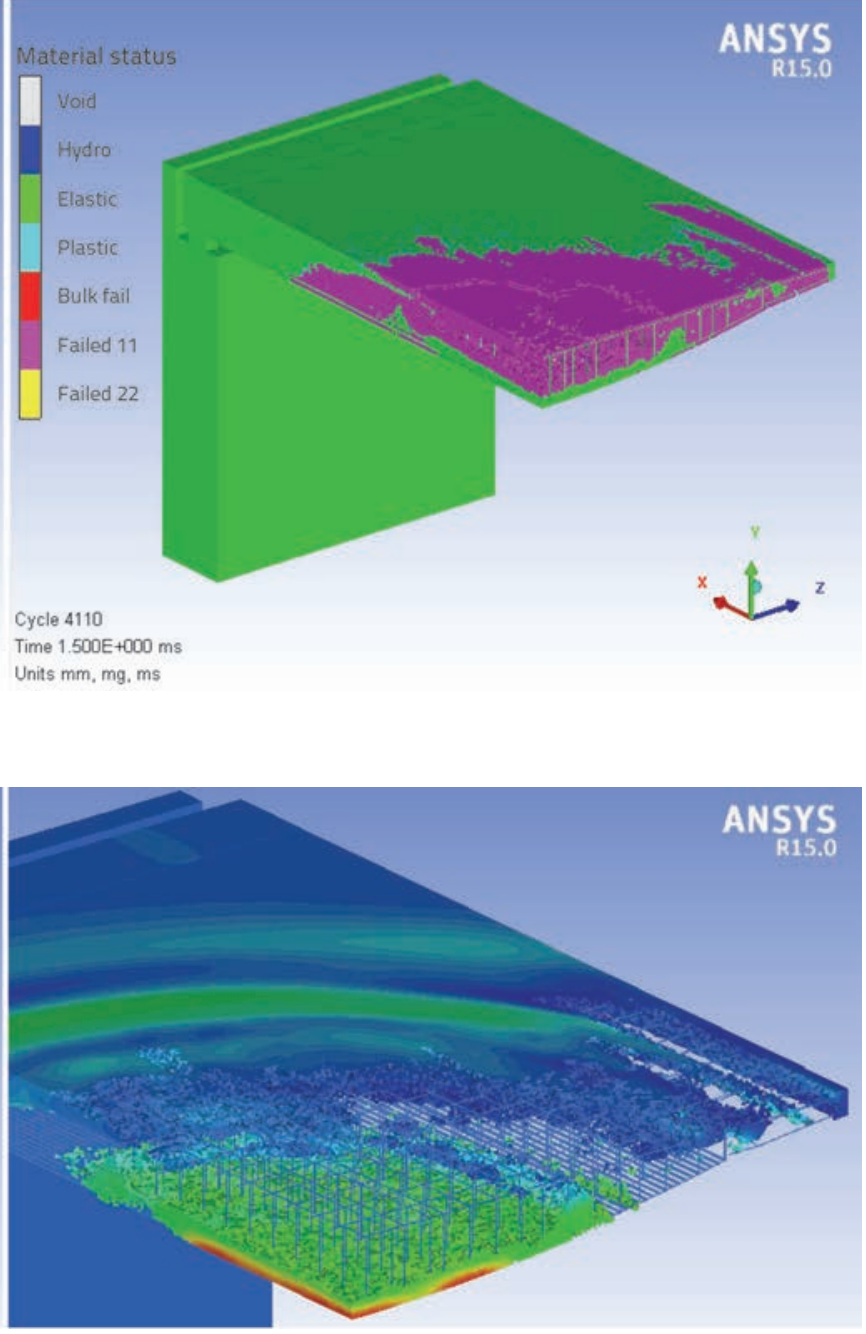

pressure action and, in this case, the asymptote is the minimum pressure that is needed to achieve a specific level of damage [55]. These diagrams are most often derived from analysis of systems with one degree of freedom, assuming that the bending is the dominant form of response, without taking into account damage due to shear. They are most frequently realized when idealised elastic-ideal plastic materials are assumed. The pressure and impulse combination from the left side and under the P-I curve will not cause failure, while the combination from the right side and above the curve causes damage that exceeds the allowed limit, i.e. the limit of damage that has been selected [56].

Four distinct cross-sectional ductility levels have been selected according to recommendations given in FEMA 426 [57] for the $\mathrm{P}-\mathrm{I}$ curve structure relating to the overpass. The top ductility level was selected for each level of damage, and P-I curves were derived based on this top level. Ductility levels are presented in Table 7, together with brief explanations for each level. The ductility values were used to calculate $\mathrm{P}-\mathrm{I}$ curves using the SBEDS software [58], which assumes that the structure is a system with one degree of freedom. 
Table 7. Relationship between level of damage and structural response

\begin{tabular}{|c|c|c|c|c|c|}
\hline $\begin{array}{l}\text { Level of } \\
\text { damage }\end{array}$ & $\begin{array}{l}\text { Deformation ratio } \\
\text { (ductility) }\end{array}$ & $\begin{array}{c}\text { Rotation of plastic } \\
\text { hinge }\end{array}$ & $\begin{array}{l}\text { Level of } \\
\text { damage }\end{array}$ & Impact on structure & $\begin{array}{c}\text { Control displacement, } \boldsymbol{X}_{\mathrm{m}} \\
{[\mathrm{mm}]}\end{array}$ \\
\hline 1 & 1 do 3 & $0^{\circ}$ do $1^{\circ}$ & $\begin{array}{l}\text { Minor } \\
\text { damage }\end{array}$ & $\begin{array}{c}\text { The structure remains } \\
\text { operational. } \\
\text { The structure can be used after } \\
\text { explosion. } \\
\text { Only minor repairs are needed. } \\
\text { Low level of possible harm } \\
\text { to persons due to structural } \\
\text { damage. }\end{array}$ & 9.04 \\
\hline 2 & 3 do 6 & $1^{\circ}$ do $2^{\circ}$ & $\begin{array}{l}\text { Moderate } \\
\text { damage }\end{array}$ & $\begin{array}{l}\text { The structure remains } \\
\text { operational. } \\
\text { The structure can not be used } \\
\text { after explosion. } \\
\text { It is necessary to make major } \\
\text { repairs the cost of which } \\
\text { approaches or exceeds } \\
\text { replacement costs. } \\
\text { People might suffer injuries } \\
\text { due to structural damage. }\end{array}$ & 18.08 \\
\hline 3 & 6 do 10 & $2^{\circ}$ do $4^{\circ}$ & $\begin{array}{l}\text { High level of } \\
\text { damage (start } \\
\text { of collapse) }\end{array}$ & $\begin{array}{l}\text { Structural safety with regard to } \\
\text { explosive action is reduced. } \\
\text { High risk of people being } \\
\text { injured due to structural } \\
\text { damage. }\end{array}$ & 30.13 \\
\hline 4 & $>10$ & $>4^{\circ}$ & $\begin{array}{l}\text { Total damage } \\
\text { and collapse }\end{array}$ & $\begin{array}{l}\text { Structure is destroyed. } \\
\text { High life-threatening hazard }\end{array}$ & 45.20 \\
\hline
\end{tabular}

In addition to P-I curves, Figure 17 shows combinations of pressure and impulse values as obtained for the overpass affected by three assumed quantities of TNT $(115 \mathrm{~kg}, 230 \mathrm{~kg}$ i $680 \mathrm{~kg}$ ). Comparison of numerical results and $\mathrm{P}$-I values reveals that values obtained for $230 \mathrm{~kg}$ and $680 \mathrm{~kg}$ of explosive are above the limit curve for ductility 15 , which means that the level of damage 4 is achieved and that the overpass will collapse if exposed to such quantities of explosive. The pair of pressure and impulse values for $115 \mathrm{~kg}$ of explosive is situated in between the curves for the levels of damage 3 and 4, which shows that the level of overpass damage is much lower compared to the other two quantities, although it still results in overpass failure.

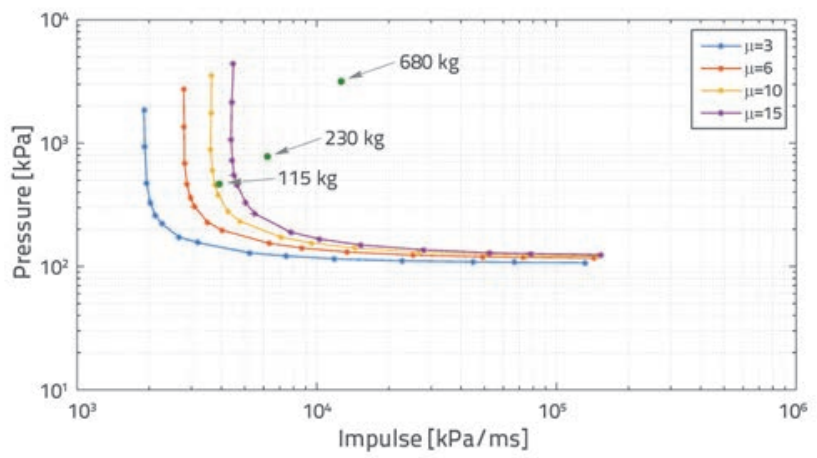

Figure 17. P-I curves for estimation of overpass damage

\section{Conclusion}

A numerical analysis of the effect of explosion on a reinforcedconcrete overpass of slab-shaped cross-section is conducted in the paper. Behaviour of two types of slab cross-section is considered, i.e. slab with the flat bottom surface and slab with the curbed bottom surface, because a different level of damage -depending on the type of cross section - is assumed. The following conclusions are made based on numerical analysis:

- propagation of the explosion wave around the overpass is of an assumed shape, i.e. after detonation the wave propagates concentrically from the source toward the overpass, collides with the superstructure, rebounds and spreads further on along the structure, "flows over" cantilevers and partly affects the top surface of the superstructure (making a "whirl" at the edges), and spreads further away into the surrounding space,

- the pressure envelope also adopts an assumed shape where the maximum pressure is in the centre of the superstructure, and its value exponentially reduces toward the ends where an additional leap occurs due to collision with the abutment; the surface is of similar shape for all observed quantities of explosive, i.e. only the top pressure value changes depending on the quantity,

- the size of the finite-element mesh influences the pressure level considerably, but it also influences the time of analysis. 
It is therefore necessary to calibrate the model so as to determine an optimum size of the mesh. For this problem, an optimum finite-element mesh size is $25 \mathrm{~mm}$,

- considering the size of the numerical model, the use was made of the symmetry and parallel analysis so as to reduce the total calculation time (computer properties: Intel(R) Xeon(R) CPU $2.4 \mathrm{GHz}$, two processors with six physical and twelve logical cores, and 48 Gb of RAM). For comparison, the computation of a three-dimensional overpass model conducted without parallel analysis lasted 14 days (336 hours) for the explosion time of $0.01 \mathrm{~ms}$, while the entire model (explosion time: $2.0 \mathrm{~ms}$ ) was calculated using parallel analysis within no more than three days (72 hours).

- equal quantities of explosive cause greater damage to flatbottomed cross-section, which is due to direct rebound and compression of oncoming air wave particles, resulting in rebound pressures that are much higher compared to initial explosion pressures,

- cross-section cantilevers with flat bottom also suffer greater damage compared to cantilevers with rounded cross section,

- in both types of cross-section, the damage and failure follow a similar pattern. The bottom surface that is directly exposed to explosive action retains its initial form while greatest damage occurs at the top surface of the superstructure. It can be observed that this top surface damage is very similar to cracking pattern noted during puncture of reinforcedconcrete slabs,

- to increase resistance of reinforced-concrete structures to detonation of explosive placed under the superstructure, the top zone must additionally be reinforced with principal longitudinal and distribution reinforcement, and with ties. The superstructure slab based on a simple beam system, as in this example, is reinforced with principal reinforcement in the bottom zone, dimensioned according to relevant design load values. However, the top zone of the slab is reinforced only with structural reinforcement that serves for preventing cracking due to concrete shrinkage, and for assuming residual transverse bending moments, and is therefore placed in much smaller quantities. In case of big exceptional load from below (explosion), the resulting stress is opposite to the stress registered during the use of the structure: the tensile zone is at the top edge, and the compression zone is at the bottom edge,

- comparison of pressure-impulse pairs obtained by numerical analysis with $\mathrm{P}-\mathrm{I}$ curves enables estimation of the level of overpass damage, and confirms the initial assumption on bridge collapse when subjected to the assumed quantities of explosive.

\section{REFERENCES}

[1] Hameed, A.H.: Dynamic Behaviour Of Reinforced Concrete Structures Subjected To External Explosion, A Thesis, Jumada Elawal, 1428 (2007).

[2] Norman, T.L.: Building Security Design Considerations: The Effects of Bomb Blasts, AIA Best Practices, 2007.

[3] Suthar, K.: The effect of dead, live and blast loads on a suspension bridge, University of Maryland, College Park, 2007.

[4] Agrawal, A. K., Yi, Z.: High Precision Analysis of Blast Events on Highway Bridges (Blast Load Effects on Highway Bridges). New York: The City Collage on New York, pp. 204, 2008.

[5] Williamson, E.B., Bayrak, O., Williams, G.D., Davis, C.E., Marchand, K.A., McKay, A.E.: Blast-Resistant Highway Bridges: Design and Detailing Guidlines. Washington, D.C.: Transportational Research Board, pp. 142, 2010.

[6] Foglar, M., Kovar, M.: Conclusions from experimental testing of blast resistance of FRC and RC bridge decks, International Journal of Impact Engineering, 59 (2013) 9, pp. 18-28, https://doi. org/10.1016/j.jijimpeng.2013.03.008

[7] Fujikura, S., Bruneau, M.: Experimental investigation of seismically resistant bridge piers under blast loading, Journal of Bridge Engineering, 16 (2010) 1, pp. 63-71.

[8] Fujikura, S., Bruneau, M.: Dynamic analysis of multihazardresistant bridge piers having concrete-filled steel tube under blast loading, Journal of Bridge Engineering, 17 (2011) 2, pp. 249-258.

[9] Fujikura, S., Bruneau, M., Lopez-Garcia, D.: Experimental investigation of multihazard resistant bridge piers having concrete-filled steel tube under blast loading, Journal of Bridge Engineering, 13 (2008) 6, pp. 586-594.
[10] Wei, J., Quintero, R., Galati, N., Nanni, A.: Failure Modeling of Bridge Components Subjected to Blast Loading Part I: Strain RateDependent Damage Model for Concrete, International Journal of Concrete Structures and Materials, 1 (2007) 1, pp. 19-28.

[11] Quintero, R., Wei, J., Galati, N., Nanni, A.: Failure Modeling of Bridge Components Subjected to Blast Loading Part II: Estimation of the Capacity and Critical Charge, International Journal of Concrete Structures and Materials, 1 (2007) 1, pp. 29-36, https://doi. org/10.4334/IJCSM.2007.1.1.029

[12] ANSYS AUTODYN User manual. ANSYS Release 140. Canonsburg, PA, USA, pp. 1-464, 2010.

[13] Hallquist, J.O.: LS-DYNA theory manual, Livermore software Technology corporation, 3 (2006) pp. 25-31

[14] ABAQUS: Theory Manual, Hibbitt, Karlsson, Sorensen, 1997.

[15] STAAD.Pro V8i (SELECTseries 4), Technical Reference Manual. In: Infrastructure BS, USA: Bentley Systems, Incorporated, pp. 775.2012.

[16] Black, G.: Computer Modeling of Blast Loading Effects on Bridges. University of Delaware, 2006.

[17] Anwarul Islam, A.K.M., Yazdani, N.: Performance of AASHTO girder bridges under blast loading, Engineering Structures, 30 (2008) 7, pp. 1922-1937

[18] Deng, R.B., Jin, X.L.: Numerical Simulation of Bridge Damage under Blast Loads, WSES Transactions on Computers, 8 (2009) 9, pp. 10.

[19] Tang, E.K.C.: Numerical Simulation of a Long Span Bridge Response to Blast Loading, The University of Western Australia, 2009. 
[20] Tang, E.K.C., Hao, H.: Numerical simulation of a cable-stayed bridge response to blast loads, Part I: Model development and response calculations, Engineering Structures, 32 (2010) 10, pp. 3180-3192.

[21] Hao, H., Tang, E.K.C.: Numerical simulation of a cable-stayed bridge response to blast loads, Part II: Damage prediction and FRP strengthening, Engineering Structures, 32 (2010) 10, pp. 31933205.

[22] Ibarhim, A., Salim, H., Rahman, N.A.: Progressive collapse of posttensioned box girder bridges under blast loads using applied element method. Structures Congress 2012, pp. 2291-2300, 2012, https://doi.org/10.1061/9780784412367.201

[23] Lau, D.T., Wibowo, H.: Seismic progressive collapse analysis of reinforced concrete bridges by applied element method Earth and Space 2010: Engineering, Science, Construction, and Operations in Challenging Environments, pp. 3019-3026, 2010.

[24] Salem, H., Mohssen, S., Nishikiori, Y., Hosoda, A.: Numerical Collapse Analysis of Tsuyagawa Bridge Damaged by Tohoku Tsunami, Journal of Performance of Constructed Facilities, 30 (2016) 6, pp. 401-6065.

[25] Meguro, K., Tagel-Din, H.: Applied element method for structural analysis: theory and application for linear analysis, Doboku Gakkai Ronbunshu, 2000 (2000) 647, pp. 31-45.

[26] ELS. Extreme Loading for Structures (ELS). Developed by Applied Science International (ASI), LLC, 3221, Wellington Court, Raleigh, NC 27615. .2006.

[27] Walter, P.L.: Introduction to Air Blast Measurements - Part I, PCB Piezotronics Inc, pp. 1-3, 2004.

[28] Walter, P.L.: Introduction to Air Blast Measurements - Part II: Interfacing the Transducer, PCB Piezotronics Inc, pp. 1-3, 2004.

[29] Walter, P.L.: Introduction to Air Blast Measurements - Part III: Guaranteeing that Validated Pressure Measurements are Acquired, PCB Piezotronics Inc, pp. 1-3, 2004.

[30] Walter, P.L.: Introduction to Air Blast Measurements - Part IV: Getting the Signal Down the Cable, PCB Piezotronics Inc, pp. 1-4, 2004.

[31] Walter, P.L.: Introduction to Air Blast Measurements - Part V: Alternate Technologies?, PCB Piezotronics Inc, pp. 1-4, 2004.

[32] Walter, P.L.: Validating the data before the structural model, Experimental Techniques, 34 (2006) 6, pp. 56-59.

[33] Kwaśniewski, L.: Application of grid convergence index in FE computation, Bulletin of the Polish Academy of Sciences: Technical Sciences, 61 (2013) 1, pp. 123-128.

[34] Bimbaum, N.K., Tancreto, J., Hager, K.: Calculation of blast loading in the high performance magazine with AUTODYN-3D. DTIC Document.1994.

[35] Courant, R., Fridrichs, K., Lewy, H.: On the Partial Difference Equations of Mathematical Physics, Mathematische Annalen, 100 (1928) pp. 32-74, https://doi.org/10.1007/BF01448839

[36] Kohnke, P.: ANSYS theory manual, Relese 12.0, ANSYS Inc, pp. 1126, 2009.

[37] Riedel, W., Thoma, K., Hiermaier, S., Schmolinske, E.: Penetration of Reinforced Concrete by BETA-B-500, Numerical Analysis using a New Macroscopic Concrete Model for Hydrocodes, 9 Internationales Symposium, Interaction of the Munitions with Structures, Berlin, pp. 1-8, 1999

[38] Riedel, W., Kawai, N., Kondo, K.I.: Numerical assessment for impact strength measurements in concrete materials, International Journal of Impact Engineering, 36 (2009) 2, pp. 283-293.
[39] Malvar, L.J., Crawford, J.E.: Dynamic increase factors for concrete, Twenty-Eighth DDESB Seminar, Orlando, Florida, USA, 1-17, 1998.

[40] Malvar, L.J., Crawford, J.E.: Dynamic increase factors for steel reinforcing bars, Twenty-Eighth DDESB Seminar, Orlando, Florida, USA, pp. 1-17, 1998.

[41] Baudin, G., Serradeill, R.: Review of Jones-Wilkins-Lee equation of state, EPJ Web of Conferences, 10 (2010), pp. 00021.

[42] Lee, E., Hornig, H., Kury, J.: Adiabatic expansion of high explosive detonation products. California Univ., Livermore. Lawrence Radiation Lab.1968, https://doi.org/10.2172/4783904

[43] Nam, J., Kim, J.H., Kim, S., Yi, N., Byun, K.: A study on mesh size dependency of finite element blast structural analysis induced by non-uniform pressure distribution from high explosive blast wave, KSCE Journal of Civil Engineering, 12 (2008) 4, pp. 259-265.

[44] Luccioni, B., Ambrosini, D., Danesi, R.: Blast load assessment using hydrocodes, Engineering Structures, 28 (2006) 12, pp. 17361744.

[45] Shi, Y., Li, Z., Hao, H.: Mesh size effect in numerical simulation of blast wave propagation and interaction with structures, Transactions of Tianjin University, 14 (2008) 6, pp. 396-402.

[46] Bazant, Z.P., Belytschko, T.B.: Wave propagation in a strainsoftening bar: exact solution, Journal of Engineering Mechanics, 111 (1985) 3, pp. 381-389.

[47] Chapman, T.C., Rose, T.A., Smith, P.D.: Blast wave simulation using AUTODYN2D: A parametric study, International Journal of Impact Engineering, 16 (1995) 5-6, pp. 777-787.

[48] Krauthammer, T., Otani, R. K.: Mesh, gravity and load effects on finite element simulations of blast loaded reinforced concrete structures, Computers, Structures, 63 (1997) 6, pp. 1113-1120.

[49] Zhao, C.F., Chen, J.Y.: Damage mechanism and mode of square reinforced concrete slab subjected to blast loading, Theoretical and Applied Fracture Mechanics, 63-64 (2013), pp. 54-62.

[50] ANSYS. Autodyn Parallel Processing Tutorial. ANSYS Release 150. Canonsburg, PA, USA p. 1-46.2013.

[51] Baker, W.E., Cox, P., Kulesz, J., Strehlow, R., Westine, P.: Explosion hazards and evaluation, Elsevier, 2012.

[52] Zadeh, R.: Pressure-impulse diagrams using finite element analysis for reinforced concrete columns subjected to blast loading, University of Missouri--Kansas City, 2011.

[53] Nalagotla, J.K.R.: Pressure-impulse diagrams using finite element analysis for reinforced concrete slabs subjected to blast loading, University of Missouri-Kansas City, 2013.

[54] Krauthammer, T., Astarlioglu, S., Blasko, J., Soh, T.B., Ng, P.H.: Pressure-impulse diagrams for the behavior assessment of structural components, International Journal of Impact Engineering, 35 (2008) 8, pp. 771-783.

[55] Shi, Y., Hao, H., Li, Z.X.: Numerical derivation of pressure-impulse diagrams for prediction of RC column damage to blast loads, International Journal of Impact Engineering, 35 (2008) 11, pp. 1213-1227.

[56] Mays, G., Smith, P.D.: Blast Effects on Buildings: Design of Buildings to Optimize Resistance to Blast Loading, T. Telford, 1995.

[57] FEMA. Reference Manual to Mitigate Potential Terrorist Attacks Against Buildins (FEMA 426). Risk Management Series: FEMA, pp. 420, 2003.

[58] Center, U.P.D. User's guide for the single-degree-of-freedom blast effects design spreadsheets (SBEDS). PDC-TR-06-02. Omaha, NE.2006. 